\title{
MAKANAN PENDAMPING AIR SUSU IBU (MP-ASI) BERKUALITAS DAPAT MELAHIRKAN GENERASI YANG BERKUALITAS
}

\author{
Pepi Hapitria $^{*}$, Entin Jubaedah1 ${ }^{\text {. Nina Nirmaya Mariani }}{ }^{1}$ \\ ${ }^{1}$ Prodi Kebidanan Cirebon, Poltekkes Kemenkes Tasikmalaya \\ *Email: hapitriapepi@yahoo.com
}

\section{ABSTRACT}

Currently, the development of nutritional problems in Indonesia is increasingly complex, the problem of malnutrition will have an impact on the disruption of growth and physical and cognitive development in infants and toddlers. The provision of complementary foods (MP-ASI), both in terms of quantity and quality, can improve the nutritional status of children. Because of that globally it is realized that the improvement in the quality and quantity of MP-ASI becomes a very important part of the future of a nation and country. Community service activities carried out at the Pamitran Community Health Center involve cadres as many as 15 people, because cadres are the closest drivers to the community and play a routine role in Posyandu activities, dealing with various community problems including the nutritional status of toddlers. The method used is descriptive to find out the increase in cadre knowledge about the basics of MP-ASI. The questionnaire is an instrument used as an interview guide in measuring knowledge. In addition to knowledge, cadres are required to be able to process food ingredients into quality MP-ASI and continue with counseling practices for mothers who have babies under two years of age. Counseling is carried out using MPASI which has been made as a medium for counseling. The results obtained were an increase in cadre knowledge about the basics of MP-ASI, the ability to process ASI skills and good counseling skills.

Keywords: Complementary foods of breast milk

\begin{abstract}
ABSTRAK
Saat ini, perkembangan masalah gizi di Indonesia semakin kompleks, masalah kekurangan gizi akan berdampak pada gangguan pertumbuhan dan perkembangan fisik serta kognitif anak. Pemberian Makanan Pendamping ASI yang baik dari segi kuantitas maupun kualitas dapat memperbaiki status gizi. Olah karena itu secara global disadari bahwa perbaikan pada kualitas dan kuantitas MP-ASI menjadi bagian penting dari masa depan suatu bangsa dan negara. Kegiatan pengabmas yang dilaksanakan di UPT Puskesmas Pamitran melibatkan kader sebagai sasaran karena kader berperan langsung dan rutin dalam kegiatan Posyandu berhadapan dengan berbagai permasalahan masyarakat termasuk masalah status gizi bayi balita. Metode yang digunakan adalah deskriptif untuk mengetahui peningkatan pengetahuan kader tentang dasar-dasar MP-ASI. Kuesioner digunakan sebagai pedoman wawancara dalam mengukur pengetahuan. Selain pengetahuan, kader dituntut untuk mampu mengolah bahan makanan menjadi MP-ASI berkualitas serta praktik konseling pada ibu baduta dengan menggunakan MP-ASI yang telah dibuat sebagai media konseling. Hasil yang diperoleh adalah adanya peningkatan pengetahuan, kemampuan keterampilan mengolah MP-ASI dan kemampuan konseling yang baik.
\end{abstract}

Kata Kunci : Makanan Pendamping Air Susu Ibu 


\section{PENDAHULUAN}

Pemenuhan gizi yang adekuat adalah merupakan salah satu hak dasar anak, yang tercantum dalam pasal 24, Konvensi Hak Anak, PBB 1989; karenanya pada tahun 2002 WHO menyusun kembali strategi "The Global Strategy for Infant and Young Child Feeding”, yaitu penekanan kembali untuk memperhatian dampak- dampak praktek pemberian makan pada bayi dan balita yang dapat mempengaruhi status gizi, pertumbuhan, kesehatan dan kelangsungan hidup generasi mendatang (Golden Period dan Golden Standar) (WHO, 2011). Strategi ini disusun berdasarkan kesimpulan-kesimpulan, usulan- usulan dan saran-saran berbagai ahli dan peneliti yang secara global terkumpul sebagai suatu rekomendasi kesehatan masyarakat untuk melindungi, mempromosikan dan mendukung ASI eksklusif 6 bulan, serta menyediakan MP-ASI yang adekuat dan aman sambil meneruskan ASI sampai anak usia 2 tahun atau lebih (Perinasia, 2013). Beberapa permasalahan terkait dengan pemberian MP-ASI diantaranya pemberiannya yang terlalu dini atau bahkan terlambat diperkenalkan dengan MP- ASI. Hal ini dapat mengakibatkan asupan gizi yang rendah serta meningkatkan risiko diare, akibatnya anak menjadi kekurangan gizi. Anak yang kekurangan gizi akan berdampak pada kondisi badan yang mudah sakit dan bila sakit lebih lama untuk sembuh.

Kekurangan gizi pada balita tidak terjadi secara tiba-tiba, tetapi diawali dari kenaikan berat badan yang tidak cukup. Sebagai upaya untuk pemantauan status gizi, Dinas Kesehatan Kota Cirebon sudah melaksanakan kegiatan Sistim Kewaspadaan Pangan dan Gizi (SKPG) yang secara berkala dilaksanakan pada Bulan Februari dan Bulan Agustus yang disebut sebagai Bulan Penimbangan Balita (BPB). Prevalensi gizi kurang (BB/TB) di Kota Cirebon sebesar 6,32\% lebih rendah dari target sasaran Pembinaan Gizi Masyarakat Kementerian Kesehatan RI Tahun 2015-2019. Hasil BPB di Kota Cirebon Tahun 2015 menunjukkan hasil bahwa jumlah balita pendek (stunting) sedikit meningkat dari Tahun 2014 yaitu 11,34\% menjadi 12,82 \% di Tahun 2015. Upaya yang telah dilakukan oleh Dinas Kesehatan Kota Cirebon untuk menangani hal tersebut antara lain pemberian PMT pemulihan bagi balita gizi kurang dan gizi buruk disemua puskesmas. Namun demikian, hal tersebut belum dapat memberikan hasil yang maksimal.(Profil Kesehatan Kota Cirebon, 2015)

Upaya lain yang dapat dilakukan untuk menekan status gizi kurang pada balita adalah dengan memberdayakan keluarga dan masyarakat (Fatimah, 2010). Menyadari akan arti pentingnya peran aktif masyarakat dalam menunjang keberhasilan pembangunan dalam bidang kesehatan, diperlukan adanya agen-agen pembangunan yang dapat menumbuhkan kesadaran masyarakat untuk berpartisipasi dalam pembangunan. Partisipasi masyarakat dalam pembangunan kesehatan yang mempunyai peran besar salah satunya adalah peran Kader Posyandu. Dalam hal ini peran Kader Posyandu yang secara langsung dan rutin dalam kegiatan Posyandu berhadapan dengan berbagai permasalahan masyarakat termasuk masalah status gizi bayi balita.

Dengan memperhatikan potensi kader dan ditunjang dengan dukungan dari UPT Puskesmas Pamitran, maka sangat penting dilakukan pendampingan untuk kader dalam upaya membuat MP-ASI yang berkualitas dan ditunjang dengan pemahaman tentang dasar-dasar MP-ASI. Sehingga harapannya hal ini dapat memberikan solusi dalam mengatasi masalah gizi pada bayi dan balita di wilayah UPT Puskesmas Pamitran. Hasil yang ditargetkan untuk luaran kegiatan ini adalah peningkatan pengetahuan dan keterampilan kader dalam pembuatan MP-ASI yang didasari oleh pemahaman tentang dasar-dasar MP-ASI yang berkualitas, tersusunnya buku pedoman kegiatan, serta 
publikasi hasil pengabmas melalui jurnal atau prosiding seminar nasional.

\section{METODE}

Metode pelaksanaan dalam kegiatan ini adalah dengan cara tatap muka, diskusi, demontrasi, bermain peran dan praktik pembuatan MP-ASI. Sasaran yang terdiri dari 15 orang kader posyandu dipersiapkan untuk memperoleh pengetahuan tentang dasar-dasar MP-ASI dan memperoleh keterampilan untuk membuat MP- ASI yang bersih, sehat serta berbahan lokal sesuai dengan tingkatan usia balita. Dasar pemilihan kader posyandu sebagai sasaran adalah kader posyandu merupakan unit pelaksana pelayanan terdekat yang ada di lingkungan masyarakat, sehingga dengan pemahaman yang baik dan keterampilan yang benar maka kader posyandu selain menjadi pelaksana pelayanan juga sebagai pemantau dan penyuluh khususnya untuk memberikan informasi tentang praktik pemberian makanan yang baik untuk anak diusia emas kepada ibu, pengasuh atau keluarga.

Kegiatan pengabdian masyarakat dilaksanakan selama dua hari berturut- turut sesuai dengan kesepakatan dengan mitra kerja dan bertempat di aula UPT Puskesmas Pamitran. Penyampaian materi menggunakan multimedia, flipchart, video dan demontrasi disesuaikan dengan materi. Materi yang disajikan sudah disusun dengan baik sehingga informasi yang disampaikan jelas dan terarah. Pengetahuan kader posyandu tentang dasardasar MP-ASI tentunya penting untuk diketahui, khususnya pengetahuan sebelum dilaksanakan kegiatan. Oleh karena itu, tim pengabmas di awal dan di akhir kegiatan terlebih dahulu membagikan kuesioner pada sasaran yang memuat pernyataan-pernyataan materi tentang dasar- dasar MP-ASI. Diakhir kegiatan, harapannya dapat diketahui seberapa besar peningkatan pengetahuan kader posyandu setelah mengikuti kegiatan ini. Instrumen untuk pengetahuan dengan menggunakan kuesioner sebagai pedoman wawancara. Wawancara yang dilakukan adalah wawancara tertutup yaitu jawaban responden atas pertanyaan yang diajukan telah tersedia dalam opsi jawaban, responden tinggal memilih jawaban yang dianggap mereka paling benar atau paling tepat. (Notoatmodjo, 2014)

Setelah memperoleh pengetahuan tentang dasar-dasar MP-ASI, di hari ke 2 kader diberi kesempatan untuk mempraktikkan cara mengolah bahan lokal yang telah tim sediakan untuk diolah menjado MP-ASI yang berkualitas sesuai dengan tahapan usia bayi dan balita. Selanjutnya MP-ASI yang telah diolah dijadikan bahan untuk konseling pada ibu baduta. Untuk mengevaluasi jalannya kegiatan maka dilaksanakan monitoring dan evaluasi (monev) secara internal oleh Unit Pengabmas Poltekkes Kemenkes Tasikmalaya Wilayah Cirebon.

\section{HASIL DAN PEMBAHASAN}

Kegiatan pengabdian masyarakat dilaksanakan selama 8 (delapan) bulan di UPT Puskesmas Pamitran sebagai mitra dan sasarannya adalah kader Posyandu sebanyak 15 orang. Tim pengabmas dalam pelaksanaannya dapat berkontribusi sesuai dengan perannya . Adapun hasil kegiatan dapat digambarkan pada tabel sebagai berikut : 
Tabel 1. Distribusi Kader Berdasarkan Karakteristik

\begin{tabular}{|c|c|c|}
\hline Karakteristik Peserta & n (20) & $\%$ \\
\hline \multicolumn{3}{|l|}{ Asal Posyandu } \\
\hline$\checkmark$ Mawar & 2 & 13,3 \\
\hline$\checkmark$ Melati & 4 & 26,7 \\
\hline$\checkmark \quad$ Janur Kuning & 3 & 20,0 \\
\hline$\checkmark$ Cempaka & 2 & 13,3 \\
\hline$\checkmark \quad$ Manggar Sari & 2 & 13,3 \\
\hline$\checkmark \quad$ Nusa Indah & 2 & 13,3 \\
\hline \multicolumn{3}{|l|}{ Umur (Tahun) } \\
\hline $41-50$ & 6 & 40,0 \\
\hline $51-60$ & 5 & 33,3 \\
\hline $61-70$ & 4 & 26,7 \\
\hline \multicolumn{3}{|l|}{ Pendidikan } \\
\hline$\checkmark$ Sarjana & 1 & 6,7 \\
\hline$\checkmark$ Diploma & 1 & 6,7 \\
\hline$\checkmark$ SMA & 9 & 60,0 \\
\hline$\checkmark$ SMP & 3 & 20,0 \\
\hline$\checkmark$ SD & 1 & 6,7 \\
\hline \multicolumn{3}{|l|}{ Lama Kader (Tahun) } \\
\hline$\checkmark \quad 1-10$ & 12 & 80,0 \\
\hline$\checkmark \quad 11-20$ & 3 & 20,0 \\
\hline
\end{tabular}

Berdasarkan tabel 1 menunjukkan bahwa jumlah kader berdasarkan asal posyandu sebagian besar dari posyandu melati yaitu 4 orang (26.7\%). Berdasarkan umur sebagian besar ada pada kelompok umur 41-50 tahun sebanyak 6 orang (40.0\%). Berdasarkan pendidikan sebagian besar ada pada kelompok pendidikan SMA sebanyak 19 orang (60.0\%). Berdasarkan lama menjadi kader sebagian besar ada pada kelompok 1-10 tahun sebanyak 12 orang $(80.0 \%)$.

Tabel 2. Distribusi Pengetahuan Dasar-dasar MP-ASI pada Kader

\begin{tabular}{ccccc}
\hline \multirow{2}{*}{ Pengetahuan } & \multicolumn{2}{c}{ Pre Test } & \multicolumn{2}{c}{ Post Tes } \\
\cline { 2 - 5 } & $\mathrm{N}$ & $\%$ & $\mathrm{~N}$ & $\%$ \\
\hline Baik & 8 & 53 & 12 & 86 \\
Cukup & 7 & 47 & 2 & 14 \\
Jumlah & 15 & 100 & 14 & 100 \\
\hline
\end{tabular}

Berdasarkan tabel 2 diperoleh hasil bahwa pengetahan kader tentang dasar-dasar MP-ASI mengalami peningkatan sebanyak $33 \%$ (Baik)

Pengetahuan dipengaruhi oleh beberapa faktor, diantaranya diantaranya adalah pengalaman, umur, tingkat pendidikan dan sumber informasi. (Notoadmojo, 2014). Pengalaman yang dimaksud dalam hal ini pengalaman menjadi kader . Dari 12 kader yang ada dalam kelompok berpengetahuan baik, adalah mereka yang telah menjadi kader rata-rata 1-10 tahun dan ditunjang dengan sumber informasi yang pernah mereka peroleh dari kegiatan - kegiatan posyandu yang secara rutin mereka ikuti. Namun dalam kegiatan 
posyandu, kader sangat jarang berkesempatan untuk langsung membuat PMT sebagai MP-ASI secara baik dan berkualitas seperti yang dipraktikkan dalam kegiatan pengabmas ini.

Selain dari pengalaman sebagai kader, tingkat pendidikan berperan dalam peningkatan pengetahuan. Mayoritas kader dengan peningkatan pengetahuan dalam kelompok baik ada pada jenjang pendidikan akhir SMA.

Keterampilan dalam mengolah MP-ASI dilakukan oleh kader yang dibagi menjadi 3 kelompok sesuai dengan tahapan pemberian MP-ASI. Selanjutnya kader diberi kesempatan untuk mempresentasikan hasil pengolahan di hadapan Kepala Puskesmas, Penanggungjawab Program Gizi dan Tim Pengabmas dan selanjutnya dievaluasi dengan memperhatikan tingkat kreatifitas, penyajian dan kerjasama dalam kelompok. Di tahap akhir, dengan melibatkan ibu baduta, peserta ditugaskan untuk melakukan konseling tentang MP-ASI yang berkualitas yang disimak oleh peserta lainnya dengan menggunakan produk hasil olahannya. Teknik konseling mengacu pada Pedoman konseling pemberian makanan pada bayi dan anak (Kemenkes RI, 2014).

\section{SIMPULAN}

1. Terdapat peningkatan pengetahuan tentang dasar-dasar MP-ASI pada kader sebagai sasaran

2. Kader mampu untuk mengolah bahan makanan lokal menjadi MP-ASI yang sesuai dengan tahapan usia bayi dan balita

3. Kader mampu melakukan konseling pada ibu baduta tentang pentingnya mengolah MP-ASI yang berkualitas sesuai tahapan usia bayi dan balita

4. Publikasi artikel masih dalam bentuk draft

\section{DAFTAR PUSTAKA}

1. WHO . Infant and Young Child Feeding Vol 155.; 2011.doi:10.1111/ j. 17408709.2009.00234.x

2. Anggraeni DA dkk (2013), Bahan Bacaan Manajemen Makanan Pendamping Air Susu Ibu (MP-ASI). Jakarta,Perinasia

3. Dinas Kesehatan Kota Cirebon (2016), Profil Kesehatan Kota Cirebon

4. Fatimah. 2010. Pengetahuan Dan Praktek Keluarga Sadar Gizi Ibu Balita. Jurnal Kesehatan Masyarakat, 4 (4), hal 23-25

5. Notoatmodjo,S (2014), "Metode Penelitian Kesehatan (Edisi Revisi)", Rineka Cipta, Jakarta

6. Kemenkes, RI (2014). Modul Pelatihan Konseling : Pemberian Makan Bayi Dan Anak.; Jakarta 